\title{
Antibacterial activity of methanolic and aqueous extracts of Ligaria cuneifolia and Tripodhantus flagellaris
}

\author{
Lucia Esther Alcaráz¹, María Rosario Fusco², Claudia Maricel Mattana1', Sara Elena Satorres', Analía \\ Liliana Laciar ${ }^{1}$
}

'Área Microbiología, Facultad de Química, Bioquímica y Farmacia, Universidad Nacional de San Luis, San Luis, Argentina, ${ }^{2}$ Área Farmacognosia, Facultad de Química, Bioquímica y Farmacia, Universidad Nacional de San Luis, San Luis, Argentina

\section{A B S T R A C T}

Ligaria cuneifolia and Tripodanthus flagellaris are two species belonging to the Loranthaceae family which is widely distributed in the central and northern areas of the Argentina Republic. The present study was conduced to test the antibacterial activity of aqueous and methanol extracts of both plants against Staphylococcus aureus ATCC 43300, Staphylococcus aureus ATCC 25923, Listeria monocytogenes CLIP 74910, Escherichia coli ATCC 35218 and Pseudomonas aeruginosa ATCC 27853 strains. Antibacterial activity was determined using the agar diffusion method (variant holes) and the minimum inhibitory concentration (MIC) by broth microdilution test at concentration ranges from 5000 to $156.25 \mu \mathrm{g} / \mathrm{mL}$. The greatest effect was observed for the aqueous and methanol extracts of $T$. flagellaris against $S$. aureus and L. monocytogenes for which the average diameters of the zones of inhibition were 15 to $16 \mathrm{~mm}$ and the MIC values were 625 to $312.5 \mu \mathrm{g} / \mathrm{mL}$. Considering the MBC/MIC ratio, MIC values of T. flagelaris aqueous extracts and MIC values of both extracts of $L$. cuneifolia showed bactericidal effect against $L$. monocytogenes. Also, both extracts of $L$. cuneifolia showed bactericidal effect against this bacterial species $(2500 \mu \mathrm{g} / \mathrm{mL})$ and bacteriostatic effect against $S$. aureus. These preliminary findings demonstrate the antibacterial activity of both plants and contribute to improve the knowledge of these species, reinforcing the importance of the ethnobotanical approach as a potential source of new bioactive substances.

Key words: Antibacterial activity; Ligaria cuneifolia; Tripodanthus flagellaris

\section{INTRODUCTION}

Plant extracts were regarded by ancient civilizations as significant agents for the treatment of various ailments. However, for some decades there was an increasing interest in plant uses and in the detection of their constituents with antibacterial activity (Alcaráz et al., 2012; Savoia et al., 2012; Abreu et al., 2012). In many places of Argentina, there is a rich tradition of using herbal medicine for the treatment of various infectious diseases, inflammations, injuries, and other diseases. (Del Vitto et al., 1997).

The mistletoe is one of the oldest known herbs with vast folkloric usage as a medicinal plant in many countries and regions of the world. Mistletoe was described as "an all purpose herb" due to its rich traditional uses and it has been widely used in ethnomedicine for various purposes (Kafaru,
1993). Mistletoes are the semiparasitic plants because they normally grow on various host trees and shrubs and they are dependent on their respective host for mineral nutrition and water, although they produce their own carbohydrates through photosynthesis (Griggs, 1991).

Since ancient times, the "mistletoe, Viscum album L." (Viscaceae) has been recognized in Europe and Asia as a therapeutic herb, with effects on the cardiovascular system and blood pressure (Griggs, 1991). In Argentina, mainly in the interior provinces, as in the rest of the world, the word "mistletoe" is applied to plants similar to $V$. album, for example Ligaria cuneifolia (Ruiz \& Pav.) Tiegh (Loranthaceae) which belongs to a different botanical family but keeps some degree taxonomic relationship with that species (Wagner et al., 1996). In Argentina, there are 7 genera and 11 species of Loranthaceae family (Del Vitto et al., 1997).

\footnotetext{
${ }^{*}$ Corresponding author:

Lucia Esther Alcaraz, Area Microbiología. Facultad de Química, Bioquímica y Farmacia, Universidad Nacional de San Luis, San Luis, Argentina. Phone: 542664 520300. Mobile: +54 2664 645055. E-mail: lucesalca@gmail.com
} 
Ligaria cuneifolia (Ruiz \& Pav.) Tiegh, popularly known as "liga", "liguilla", "liga roja", or "muérdago criollo" and Tripodanthus flagellaris (Cham\& Schlchdtl). Tiegh, known as "liga blanca", "liguilla", "corpo", "liga", "pupusa", are two species belong to the Loranthaceae family widely distributed in the central and northern areas of the Argentina Republic between 1800 and $2700 \mathrm{~m}$ on the sea level. These species are shrubby plants hemiparasite, evergreen, living in epiphyte on trees and shrubs. L. cuneifolia present woody stems and leaves are alternate, simple, lanceolate. Its flowers are very showy, red (or yellow) color (Figure 1).

In folk medicine, the infusion of these plants are used as hypotensive and to reduce excess cholesterol. Also, their anti-carcinogenic, anti-diabetic and anti-HIV activities have been reported (Dominighini et al., 2010; Fernandez et al., 1998). Tripodanthus flagellaris is used mainly as cardioactive drug in Cuyo region (Argentina) (Del Vitto et al., 1997; Fusco et al., 2010).

There are some studies on the biological activities of L. cuneifolia and T. flagellaris (Fusco et al., 2001; Fusco et al., 2004; Fusco et al., 2010; Ferrero et al., 2006; Dominighini et al., 2010). Few researchers have reported antibacterial activity of Loranthaceae species (Varela et al., 2001; Ukwueze et al., 2013). However, some researches suggested that several factors play important roles in the phytochemical composition and pharmacological activities of the mistletoe plants. Such factors include: the host, specie of mistletoe used, season of harvest, etc. (Osadebe and Ukwueze, 2004; Wagner et al., 1996; Osadebe et al., 2008; Yusuf et al., 2013).

Prevoius phytochemical studies on L. cuneifolia indicated the presence of tannins, flavonoids, saponins, anthraquinones, alkaloids and cardiac heterosides (Fusco et al., 2001; Fusco et al., 2004). Antibacterial activity of some of these

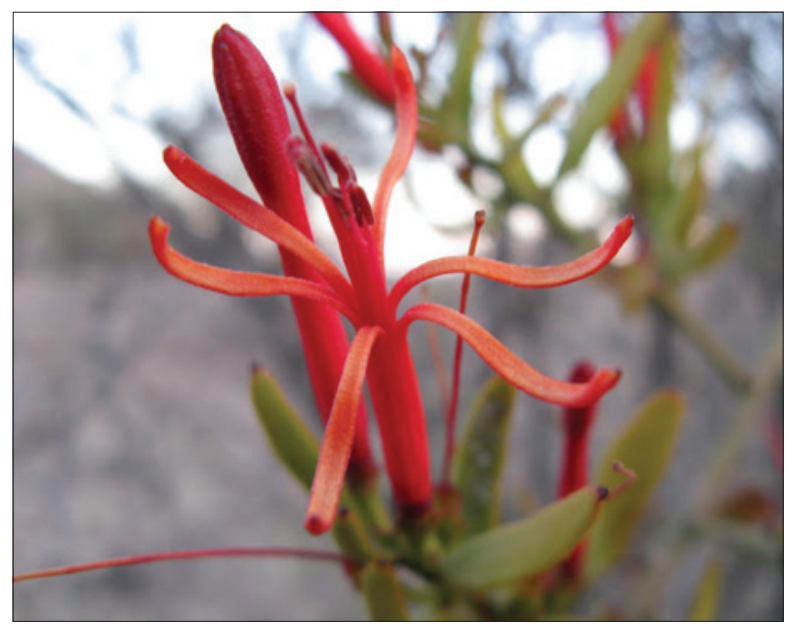

Fig 1. Flowers and leaves of $L$. cuneifolia phytochemicals has been shown (Alcaráz et al., 2000; Takhi et al., 2011. In Argentina, has been reported only a study on the antibacterial activity of L. cuneifolia in Tucuman (Soberón et al., 2014), while no information regarding the antibacterial activity of T. flagellaris was found.

In the present study, our purpose was evaluated the antibacterial activity of aqueous and methanolic extracts from these two native plants against Gram positive and Gram negative pathogenic bacteria species.

\section{MATERIALS AND METHODS}

\section{Plant material}

The L. cuneifolia and T. flagelaris samples (branches with leaves and flowers) were collected in the Province of San Luis, Argentina in El Milagro (Dpto. Pueyrredón) and La Florida (Dpto. Coronel Pringles), respectively, and were authenticated by Dr. Del Vitto, Botany Department, San Luis National University (UNSL). The voucher specimen of $L$. cuneifolia was deposited in the herbarium of UNSL under the number 9245 (UNSL) and T. flagelaris under the number 8553 (UNSL).

\section{Preparation of extracts}

The plants materials were dried in open air at room temperature, and finely ground with a hammer mill.

\section{Aqueous extracts}

Dried and powdered plant material $(5 \mathrm{~g})$ was boiled with $70 \mathrm{ml}$ of water for $20 \mathrm{~min}$. After cooling to $40-45^{\circ} \mathrm{C}$, the liquid was filtered and the volume adjusted to $100 \mathrm{ml}$ with distilled water and then lyophilized (Kuklinski, 2000).

\section{Methanolic extracts}

A known amount of powdered plant material $(100 \mathrm{~g})$ was extracted overnight with methanol (Merck), under gentle shaking. The extracts were filtered through Whatman $\mathrm{N}^{\circ}$ 4 filter paper, dried under reduced pressure at $40^{\circ} \mathrm{C}$, and weighed (Kuklinski, 2000).

The methanolic extract was dissolved in dimethylsulfoxide (DMSO) and the aqueous extract was dissolved in water. Later, they were diluted to the highest concentration to be tested $(5,000 \mu \mathrm{g} / \mathrm{mL})$ and then, serial two-fold dilutions were made in concentration ranges from 5,000 to $156,25 \mu \mathrm{g} / \mathrm{mL}$.

\section{Microorganisms}

Antibacterial activity of the extracts was tested individually on clinically important reference bacterial strains. The Gram-positive bacterial strains used were Staphylococus aureus ATCC 43300, Staphylococcus aureus ATCC 25923 and Listeria monocytogenes CLIP 74910. The Gram-negative 
bacterial strains used were Escherichia coli ATCC 35218 and Pseudomonas aeruginosa ATCC 27853. ATCC strains were provided by the Institute Malbrán (Argentina) and L. monocytogenes CLIP 74910 was obtained from the Listeria Collection of the Pasteur Institute, Paris. Bacterial strains were maintained on tryptycase soy broth supplemented with $20 \%$ glycerol at $-80^{\circ} \mathrm{C}$ until use. Before testing, the suspensions were transferred to nutrient broth (Difco) and cultured overnight at $37^{\circ} \mathrm{C}$. Inocula were prepared by adjusting the turbidity of the suspension to match the $0.5 \mathrm{McF}$ arland standard $\left(10^{8}\right.$ bacterial cells). Then, they were diluted 10 times.

\section{Antibacterial testing}

\section{Agar diffusion assay}

Antibacterial activity of the crude methanol extracts and aqueous extract were determined by the modified agar well diffusion method (Perez et al., 1990). Mueller-Hinton agar (MHA, Britania, Argentina) $25 \mathrm{~mL}$ was poured into each petri plate. Once the agar solidified, the microorganisms were inoculated on the surface of the plates $\left(1 \times 10^{8} \mathrm{CFU} /\right.$ $\mathrm{mL})$. Subsequently, the surface of the agar was punched with a 6-mm-diameter wells. Each well was filled with $50 \mu \mathrm{L}$ of each plant extract. Simultaneously, wells containing the same volume de DMSO and distilled water served as negative controls. Gentamicin sulfate $(1 \mu \mathrm{g}$ per well) was used as positive control. After a 24-hours incubation at $35^{\circ} \mathrm{C}$, all plates were observed for zones of growth inhibition, and the diameter of these zones was measured in millimetres.

All tests were performed in duplicate and the antibacterial activity was expressed as the mean of inhibition diameters $(\mathrm{mm})$ produced.

\section{Determination of Minimum Inhibitory Concentration (MIC)}

Methanol and aqueous extracts were further tested to determine the minimum inhibitory concentration (MIC) for each bacterial strain. The MIC values were determined by broth microdilution test using 96-well microplate (CLSI, 2011). In each well, $95 \mu \mathrm{L}$ triptone soy broth supplemented with $0.01 \% 2,3,5$,-trifenyltetrazolium as visual indicator of bacterial growth, $5 \mu \mathrm{L}$ of a suspension of $10^{7} \mathrm{CFU} /$ $\mathrm{mL}$ strains and $100 \mu \mathrm{L}$ serial dilution in base two (8000 to $125 \mu \mathrm{g} / \mathrm{mL}$ ) of the extracts were added. The final volume in each well was $200 \mu \mathrm{L}$. The plates were covered with sterile plate sealer and then incubated aerobically at $37^{\circ} \mathrm{C}$ for $24 \mathrm{~h}$ and read visually. MIC was defined as the lowest concentration of the extract in the medium in which there was no visible growth after incubation. Media, extract and strains controls were included. The test was performed in duplicate and then replicated at least three times. The plates were incubated at $37^{\circ} \mathrm{C} 24 \mathrm{~h}$.

\section{Determination of Minimal Bactericidal Concentration (MBC)}

Extracts that showed inhibitory activity in the preliminary broth assay were submitted to a subculture on the surface of the tripticase soya agar plates, in order to evaluate bacterial growth. MBC was determined as the lowest concentration that showed no bacterial growth in the subcultures after $24 \mathrm{~h}$ of aerobic incubation at $37^{\circ} \mathrm{C}$.

\section{Statistical analysis}

The experiments were replicated three times and were expressed as mean value \pm standard error of the mean of growth inhibition zones diameters obtained with those natural products which amount was sufficient to perform repetitions.

\section{RESULTS AND DISCUSSION}

The antibacterial activity of aqueous and organic extracts from L. cuneifolia and T. flagelaris was assayed in vitro conditions by agar well diffusion and broth microdilution methods against $S$. aureus, L. monocytogenes, E. coli and $P$. aeruginosa. Inhibition of bacterial growth by the action of the aqueous and methanolic extracts according to the agar well diffusion method is summarized in Table 1. Although the diameters of the inhibition halos are minor compared to commercial antibiotic, the results are interesting, because the total extract was assayed, and no pure compounds.

All extracts were active against gram-positive bacteria and showed no activity against Gram-negative bacteria at the concentrations tested. A slightly greater inhibitory effect was observed in both extracts of Tripodhantus flagelaris against $S$. aureus and $L$. monocytogenes for which the average diameters of the zones of inhibition were ranged between 15 and $16 \mathrm{~mm}$. Table 2 show the results of the MIC of aqueous and methanolic extracts of the two plants against strains studied using the broth microdilution method.

There was correlation between the two methods tested. The MIC values of both extracts of T. flagellaris against both strains of $S$. aureus were the lowest (MIC values were of $625 \mu \mathrm{g} / \mathrm{mL}$ ) being the methanolic extract of $T$. flagellaris (MIC values were of $321.5 \mu \mathrm{g} / \mathrm{mL}$ ) slightly more active against $S$. aureus ATCC 43300 (methicillin resistant). There was no difference in the activity of the extracts of both plants among methicillin-sensitive and methicillin-resistant Staphylococcus aureus. These results indicate that antibiotic resistance does not interfere with the antimicrobial activity of plant extracts and extracts could have different modes of action on microorganisms studied. 
Table 1: Antibacterial activity of aqueous and methanolic extracts of L. cuneifolia and $T$. flagelaris by agar well diffusion assay

\begin{tabular}{|c|c|c|c|c|c|}
\hline \multirow[t]{3}{*}{ Microorganisms } & \multicolumn{5}{|c|}{ Inhibition (mm) } \\
\hline & \multicolumn{2}{|c|}{ L. cuneifolia } & \multicolumn{2}{|c|}{ T. flagelaris } & \multirow[t]{2}{*}{ Gentamicin } \\
\hline & $\mathrm{AE}$ & ME & $\mathrm{AE}$ & ME & \\
\hline S. aureus ATCC 43300 & $17.4 \pm 0.3$ & $17.2 \pm 0.2$ & $15.1 \pm 0.1$ & $15.2 \pm 0.2$ & $21.2 \pm 0.2$ \\
\hline S. aureus ATCC 25923 & $17.4 \pm 0.3$ & $17.3 \pm 0.2$ & $15.3 \pm 0.2$ & $15.4 \pm 0.3$ & $20.1 \pm 0.2$ \\
\hline E. coli ATCC 35218 & $\mathrm{n} / \mathrm{i}$ & $n / i$ & $n / i$ & $\mathrm{n} / \mathrm{i}$ & $20.4 \pm 00$ \\
\hline L. monocytogenes CLIP 74910 & $18.2 \pm 0.2$ & $18.3 \pm 0.1$ & $15.2 \pm 0.1$ & $16.2 \pm 0.2$ & $30.2 \pm 0.4$ \\
\hline P. aeruginosa ATCC 27853 & $\mathrm{n} / \mathrm{i}$ & $\mathrm{n} / \mathrm{i}$ & $\mathrm{n} / \mathrm{i}$ & $\mathrm{n} / \mathrm{i}$ & $18.0 \pm 0.1$ \\
\hline
\end{tabular}

${ }^{*} \mathrm{AE}$ : Aqueous extracts; ${ }^{*} \mathrm{ME}$ : Methanolic extracts; $\mathrm{n} / \mathrm{i}$ : No inhibition. The dates represent the mean \pm standard error of the mean values of three different experiments

The methanolic and aqueous extracts of T. flagellaris were the most actives (MIC values 312.5 and $625 \mu \mathrm{g} / \mathrm{mL}$ respectively) against Listeria monocytogenes. Although no differences in antibacterial activity of aqueous extract compared to methanol L. cuneifolia extract were observed, the methanol extract from $T$. flagellaris was slightly more active against both Gram-positive bacteria, partially coinciding with other studies reporting that alcohol is a better solvent for extraction of antimicrobial substances from medicinal plants than water (Eloff, 1998).

According to MIC, tested extracts were inactive against gram negative bacteria coinciding with results obtained previously by agar well diffusion method. These results are consistent with some studies where the Gram-positive bacteria are more sensitive to plant extracts than Gramnegative bacteria. Probably, this fact may be due to the relatively impermeable outer membrane that surround Gram-negative bacteria.

There is little scientific information concerning to the antimicrobial activity of L. cuneifolia and T. flagelaris in Argentina. A study on L. cuneifolia performed in Tucumán, Argentina, reported MIC values inferior to our results (Soberón et al., 2014). However, it is difficult to compare the data because several variables influence the results, such as the environmental and climate conditions of the plant and the choice of the extraction method and antimicrobial tests. Furthermore, some authors report the presence of different active metabolites in Loranthaceae species according to the host tree (Osadebe and Ukwueze, 2004; Osadebe and Akabogu, 2006).

Table 3 shows MBCs values of methanolic and aqueous extracts against gram-positive bacteria. In order to elucidate if the observed antibacterial effects were bactericide or bacteriostatic, MBC/MIC ratios were calculated. Extracts with ratios greater than 1 were considered as bacteriostatic, while extracts with ratio less than or equal to 1 were bactericide. These data allow concluding that MIC values of both extracts of $L$. cuneifolia were bactericidal against
Table 2: Minimal inhibitory concentration (MIC) of aqueous and methanolic extracts of $L$. cuneifolia and $T$. flagelaris by micro-well dilution method

\begin{tabular}{lccccc}
\hline Microorganisms & \multicolumn{4}{c}{ MIC $(\mu \mathrm{g} / \mathrm{mL})$} \\
\cline { 2 - 3 } & \multicolumn{1}{c}{ L. cuneifolia } & & T. flagelaris \\
\cline { 2 - 3 } \cline { 6 - 7 } & AE & ME & & AE & ME \\
\hline S. aureus ATCC 43300 & 1250 & 1250 & & 625 & 312.5 \\
S. aureus ATCC 25923 & 1250 & 1250 & & 625 & 625 \\
E. coli ATCC 35218 & $\mathrm{n} / \mathrm{i}$ & $\mathrm{n} / \mathrm{i}$ & & $\mathrm{n} / \mathrm{i}$ & $\mathrm{n} / \mathrm{i}$ \\
L. monocytogenes CLIP 74910 & 2500 & 2500 & & 625 & 312.5 \\
P. aeruginosa ATCC 27853 & $\mathrm{n} / \mathrm{i}$ & $\mathrm{n} / \mathrm{i}$ & & $\mathrm{n} / \mathrm{i}$ & $\mathrm{n} / \mathrm{i}$ \\
\hline
\end{tabular}

AE: Aqueous extracts; ME: Methanolic extracts ; $n /$ i: No inhibition

Table 3: Minimal bactericidal concentration (MBC) of methanolic and aqueous extracts of $L$. cuneifolia and T. flagelaris against gram-positive bacteria

\begin{tabular}{lccccc}
\hline Microorganisms & \multicolumn{4}{c}{ MBC $(\mu \mathrm{g} / \mathrm{mL})$} \\
\cline { 2 - 3 } & L. cuneifolia & & T. flagelaris \\
\cline { 2 - 3 } \cline { 6 - 7 } & AE & ME & & AE & ME \\
\hline S. aureus ATCC 43300 & 2500 & 2500 & & 1250 & 1250 \\
S. aureus ATCC 25923 & 2500 & 2500 & & 1250 & 1250 \\
L. monocytogenes CLIP 74910 & 2500 & 2500 & & 625 & 625 \\
\hline
\end{tabular}

AE: Aqueous extracts; ME: Methanolic extracts; n/i: No inhibition

L. monocytogenes $(2500 \mu \mathrm{g} / \mathrm{mL})$. Similarly, the MIC values of aqueous extracts of T. flagelaris were bactericidal against these bacterial species.

Further, according to the MBC/MIC relationship, the antibacterial effect of the other active extracts against these Gram-positive species is considered bacteriostatic.

Previous phytochemical screening of these plants were positive for tannins, flavonoids, saponins, anthraquinones, alkaloids and cardiac glycosides (Fusco et al., 2001). Also, these authors, in another study, demonstrate, by spectrophotometric methods the presence of betulin and betulinic acid in the dichloromethane extract L. cuneifolia (Fusco et al., 2004). It is known that some metabolites such as flavonoids and terpenoids are synthesized by plants in response to microbial infection, and in fact, has been found in various studies that they are effective antimicrobial agents against a broad range of microorganisms (Himejima et al., 1992). While quercetin 
glycosides had previously been found in Ligaria cuneifolia as the only one flavonol, other authors first described the presence of a kaempferol glycoside in this plant (Soberon et al., 2014) While these plants are used in folk medicine as hypotensive and to reduce excess cholesterol, the data found demonstrate the antimicrobial activity of some of its components.

These preliminary findings represent a contribution to a better knowledge of these plants, used in folk medicine and suggest extending the popular use to other conditions and further, reinforce the importance of the ethnobotanical approach as a potential source non expensive as well as available of new bioactive substance.

\section{ACKNOWLEDGEMENT}

This work is part of the Project 8802 financed by University National of San Luis, Argentina. The authors also acknowledge the organizers of XXIII SILAE Congress Marsala, Sicilia -Italia, 7-12 September 2014, where this paper was presented

\section{Author contributions}

L.E.A: Designed the study, did the analysis and wrote the article. M.R.F: performed harvesting of plants and obtaining extracts. C.M.M and S.E.S: participated in designing and carrying out experiments. A.L.L: supervised this research work and corrected the article.

\section{REFERENCES}

Abreu, A. C., A. J. McBain and M. Simões. 2012. Plants as sources of new antimicrobials and resistance-modifying agents. Nat. Prod Rep. 29(9): 1007-1021.

Alcaráz, L. E., S. E. Blanco, O. N. Puig, F. Tomas and H. F. Ferretti. 2000. Antibacterial activity of flavonoids against methicillinresistant Staphylococcus aureus strains. J. Theor. Biol. 205: 231-240.

Alcaráz, L. E., C. M. Mattana, S. E. Satorres, E. Petenatti, M. Petenatti, L. Del Vitto and A. Laciar. 2012. Antibacterial activity of extracts obtained from Senna corymbosa and Tipuana tipu. Pharmacol. Online. 3: 158-161.

Clinical Laboratory Standards Institute (CLSI). 2011. Performance Standards for Antimicrobial Susceptibility Testing; M100-S21. Wayne, Pensylvannia, USA, 31.

Del Vitto, L.A., E. M. Petenatti and M. E. Petenatti. 1997. Recursos herbolarios de San Luis (Argentina). Primera parte: Plantas nativas. Multequina. 6: 49-66.

Dominighini, A., M. Ferrero, D. Crosetti, L. Alvarez Mde, M.T. Ronco, J. Gonzálvez, M. Wagner, A. Gurni, C. Carnovale and A. Luquita. 2010. Effect of Ligaria cuneifolia catechin and quercetinenriched fractions on hemorheology and plasma cholesterol. Clin. Hemorheol. Microcirc. 44: 217-225.

Eloff, J. N. 1998. Which extractant should be used for the screening and isolation of antimicrobial components from plants? J. Ethnopharmacol. 60: 1-8.

Fernández, T., M. L. Wagner, B. G. Varela, R. A. Ricco, S. E.
Hajos, A. A. Gurni and E. Alvarez. 1998. Study of an argentine mistletoe, the hemiparasite Ligaria cuneifolia (R. et P.) Tiegh. (Loranthaceae). J Ethnopharmacol. 62: 25-34.

Ferrero, M., D. Crosetti, A. Dominighini, L. Alvarez Mde, M. T. Ronco, J. Gonzálvez, M. Wagner, A. Gurni, C. Carnovale and A. Luquita. 2006. Fracción metanólica de Ligaria cuneifolia "muérdago criollo": Efecto sobre parámetros hemorreológicos y secreción biliar. Dominguezia. 22: 27-33.

Fusco, M. R., A. Sosa, M. E. Petenatti, L. A. Del Vitto, J. Saad and E. M. Petenatti. 2010. Pharmacognostical characterization of Tripodanthus flagellaris "Liga blanca" or "liguilla" in the CentralWestern Argentina. Biocell. 34(1): 79.

Fusco, M. R., E. Petenatti, P. N. Inostroza, B. A. San-Martín and L. P. Rivera. 2004. Principios activos de la Ligaria cuneifolia. Una planta medicinal. Cien. Trabajo. 6: 79-82.

Fusco, M. R., E. M. Petenatti., M. E. Petenatti and L. A. Del Vitto. 2001. Screning botanical and chemical studies in Argentine cardiotonic drugs II. Ligaria cuneifolia (Loranthaceae). Fourth International Congress of Medicinal Plants, Chile, 4-6-October.

Griggs, P. 1991. Mistletoe: Myth, magic and medicine. Biochemistry. 13: 3-4.

Himejima, M., K. R. Hobson, T. Otsuka, D. L. Wood and I. Kubo. 1992. Antimicrobial terpenes from oleoresin of ponderosa pine tree Pinus ponderosa: A defense mechanism against microbial invasion. J. Chem. Ecol. 18: 1809-1818.

Kafaru, E. 1993. Mistletoe: An example of an all-purpose herb' Herbal Remedies. Guardian Newspaper. 3: 11.

Kuklinski, C. 2000. Farmacognosia. Omega S.A, España.

Osadebe, P. O. and I. C. Akabogu. 2006. Antimicrobial activity of Loranthus micranthus harvested from kola nut tree. Fitoterapia. 77: 54-56.

Osadebe, P. O., C. A. Dieke and F. B. C. Okoye. 2008. A study of the seasonal variation in the antimicrobial constituents of the leaves of Loranthus micranthus sourced from Percia americana. Res. J. Med. Plant. 2: 48-52.

Osadebe, P. O. and S. E. Ukwueze. 2004. A comparative study of the phytochemical and antimicrobial properties of the Eastern Nigeria species of African Mistletoe (Loranthus micranthus) sourced from different host trees. J. Biol. Res. Biotechnol. 2: $18-23$

Perez, C., M. Pauli, M and P. Bazevque. 1990. An antibiotic assay by the agar well diffusion method. Acta Biol. Med. Exp. 15: 113-115.

Savoia, D. 2012. Plant-derived antimicrobial compounds: Alternatives to antibiotics. Future Microbiol. 7(8): 979-990.

Soberón, J. R., M. A. Sgariglia, M. R. Dip Maderuelo, M. L. Andina, D. A. Sampietro and M. A. Vattuone. 2014. Antibacterial activities of Ligaria cuneifolia and Jodina rhombifolia leaf extracts against phytopathogenic and clinical bacteria. J. Biosci. Bioeng. [In Press].

Takhi, D., N. Quinten and M. Yousfi. 2011. Study of antimicrobial activity of secondary metabolites extracted from spontaneous plants from the Area of Laghouat, Algeria. Adv. Environ. Biol. 5: 469-476.

Ukwueze, S. E., P. O. Osadebe and N. O. Ezenobi. 2013. Bioassayguided evaluation of the antibacterial activity of Loranthus species of the African mistletoe Int. J. Pharm. Biomed. Res. 4(2): 79-82.

Varela, B. G., T. Fernández, C. Taira, P. Cerdá Zolezzi, R. Ricco, E. Caldas López, E. Álvarez, A. A. Gurni, S. Hajos, Wagner M. L. 2001. El "Muérdago Criollo", Ligaria cuneifolia (r. et p.) Tiegh.Loranthaceae- desde el uso popular hacia el estudio de los efectos farmacológicos. Dominguezia. 17(1): 31-50. 
Wagner, M. L., T. Fernandez, E. Alvarez, R. A. Ricco, S. Hajos and A. A. Gurni. 1996. Micromolecular and macromolecular comparison of Argentina mistletoe (Ligaria cuneifolia) and European mistletoe (Viscum album L.). Acta Farm. Bonaer. 15(2): 99-108.
Yusuf, L., M. K. Oladunmoye, A. O. Ogundare, F. A Akinyosoye, G. F. Hassan G. F and A. O. Momoh. 2013. Comparative antibacterial studies of mistletoes growing on two different host plants in Akure North, Nigeria. Int. J. Med. Med. Sci. 3(5): 9-11. 